\title{
Optimization of Self-Micro Emulsifying Drug Delivery System) for Soursop Leaf (Annona muricata Linn.) Chloroform Extract
}

\author{
Anif Nur Artanti ${ }^{1}$, Fea Prihapsara ${ }^{2}$, Dian Eka Ermawati ${ }^{1}$, Aprilia Saefanan Shofa ${ }^{2}$ \\ ${ }^{1}$ Division of Pharmacy, Sekolah Vokasi, Sebelas Maret University \\ ${ }^{2}$ Department of Pharmacy, Matematic and Sains Faculty of Sebelas Maret University
}

\begin{abstract}
Soursop leaf chloroform extract has anticancer activity. The active ingredient of soursop leaf was acetogenin polypoid derivatives that have a lipophilic characteristic, and less effective to achieve action targets of drugs in biological systems. The Self-Micro Emulsifying Drug Delivery System (SMEDDS) was an effective drug delivery technique that increases the solubility of lipophilic drugs. This study aims to determine the proportion of optimum SMEDDS formula using Simplex Lattice Design (SLD) method. The Formula of SMEDDS was prepared using a combination of Tween 80-Croduret, Propylene Glycol, and Candlenut oil. Optimization formula with SLD method using Design-Expert software based on physical stability parameters there are the percent of transmittance and emulsification time. The optimum formula of SMEDDS was compared with SLD prediction formula using a statistical analysis t-test, then test of loading dose extract, stability test accelerated by centrifugation, particle size, and zeta potential. The proportion of optimum composition of Tween 80-Croduret, Propylene Glycol, and Candlenut oil of SMEDDS was $60.87 \% ; 24.13 \% ; 15.00 \%$ respectively. Results of transmittance $41.14 \pm 3.78 \%$ and emulsification time 119.0 \pm 2.08 seconds. The predicted SLD value for the transmittance percent was $55.0 \%$ and the emulsification time was 119.59 seconds. The result of the statistical analysis of one sample t-test showed no significant difference between observation results and SLD prediction. The SMEDDS system has F value of 0.99 and capable to load $25.0 \mathrm{mg}$ chloroform extract of soursop leaf each system with an average particle size of 440 $\mathrm{nm}$ and zeta potential of $+21.5 \mathrm{mV}$.
\end{abstract}

Keywords: SMEDDS; SLD; soursop leaf; chloroform extract

\section{INTRODUCTION}

The natural ingredients of active compounds of extract for medical treatment were considered safer than synthetic drugs because it was easy to obtain, has low side effects, did not cause interaction and dependence (Lynch and Berry, 2007). Soursop (Annona muricata L.) was one of Indonesia's native plants widely used in traditional medicine, especially cancer therapy and parasitic infections (Moghadamtousi et al., 2015). According to De Melo., et al. (2010) methanol extract A. muricata L. has potential as anti-cancer in HEp-2 (laryngeal cancer) and NCI-H292 (lung cancer), ovarian cancer, myeloma and murine leukemia in white mouse (Mc Laughlin et al., 2009), Hep-G2 and Hep-2 hepatoma 2.2.15 (Liaw et al., 2002), as well as a cancer-induced virus to (Astirin et al., 2013).

Chloroform extract and the fraction of soursop leaf acetogenins resulted in a higher apoptosis rate compared to ethyl acetate solvent which was $91.86 \%$ at $2000 \mathrm{ng} / \mathrm{mL}$ concentration, while in ethyl acetate extract $23.79 \%$ (Astirin et al., 2013). Paulinus et al., (2013), suggests that Annona muricata ethanol extract at a dose of $100 \mathrm{mg} / \mathrm{kg}$ body weight has protective activity against rat's

*Corresponding author : Anif Nur Artanti

Email : anif.apt@staff.uns.ac.id colon that induced colorectal carcinogen. Acetogenins polyamide derivatives are composed of 32 or 37 unbranched carbon chains attached to the 2-propanol group in $\mathrm{C}-2$ to form a lactone (Zuhud, 2011), which have low solubility in water. The active ingredients with low solubility to achieve therapeutic effects require larger doses.

Formulation technology to improve the bioavailability of drugs that were less soluble in water by using inclusion technique, which was the delivery of lipid-based drugs (Kuentz, 2011). Drugs in the form of oil droplets were more easily absorbed orally through lipid absorption mechanisms such as endocytosis, passive diffusion, or pinocytosis (Rao et al., 2008). Selfmicroemulsifying drug delivery system (SMEDDS) was one of drug delivery techniques to overcome the solubility problem of lipophilic drugs. Microemulsions had a particle size range of 100$500 \mathrm{~nm}$ (Khan et al., 2011), small size makes the surface area of the absorption larger, so increasing the solubility of lipophilic compounds in water as well as increasing the bioavailability of orally administered drugs (Wang et al. 2014). SMEDDS will form an oil in water emulsion $[\mathrm{o} / \mathrm{w}]$ in the gastrointestinal tract spontaneously, the presence of surfactant will alter the permeability and increase the solubility of the drug, and protect from hydrolysis by enzymes, thus increasing drug 
absorption and distribution (Rao et al., 2008). SMEDDS consists of surfactants, co-surfactants, and oils with the appropriate composition to create stable isotropic mixtures.

The oil phase that was used in this study was the candlenut oil (Aleurites moluccana), a longchain C-14 fatty acid, rich in linoleic and unsaturated fatty acids (Ako et al., 2005). The surfactant that used was a combination of Tween 80-Croduret, and co-surfactant was propylene glycol. Based on research Saryanti [2016] has done optimization of surfactant composition, cosurfactant, and candlenut oil with Simplex Lattice Design method. The upper limit of each component was 1: 4: 1 and the lower limit 1: 3: 1 then analyzed using Design-Expert software. This system can produce oil droplets of $15.5 \mathrm{~nm}$, zeta potential $38.9 \mathrm{mV}$, 92\% transmittance, 40 seconds emulsion time in AGF (artificial gastric fluid) media, and able to load extract up to $120 \mathrm{mg} / \mathrm{g}$ each system. The purpose of this study was to obtain the optimum proportion of surfactant, co-surfactant, and candlenut oil by adopting system formula of Saryanti (2016) to produce SMEDDS of soursop leaf chloroform extract with good physical stability including percent transmittance, emulsification time, accelerated stability, particle size, zeta potential and ability to load soursop leaf of chloroform extract.

\section{METHODOLOGY \\ Materials}

Fresh Leaf of Annona muricata L. was obtained from Jaten, Karanganyar District of Central Java; chloroform pro analytic (Merck); TLC plate (silica gel 60 GF254 Merck); candlenut oil (CV. Agung Jaya), croduret 50 ss (Croda, Ltd.), tween 80 (PT. Bratachem), and propylene glycol (PT. Bratachem).

The instruments used were spectrophotometer UV-Vis (THERMO SCIENTIFIC), analytical balance (OHAUSS), Particle Size Analyzer dan Zeta Sizer (HORIBA SZ-100).

\section{Methods}

Preparation of soursop leaf chloroform extract Fresh Leaf of Annona muricata L. picked at 4 th to 10 th leaf from the tip of twig, washed and drained in the oven at a temperature of $40-60^{\circ} \mathrm{C}$. Soursop leaf that have been dried and blended to be powdered.

Extraction process with percolation method: soursop leaf powder of 100 gram inserted into the percolator, then added 1.25-liter chloroform solvent until all powder submerged with solvent. The percolator's crane was opened so the liquid of the percolate can flow for 24 hours, then percolated with a new solvent for 24 hours. The collected percolate was stored in a sealed container and was protected from light, then evaporated using a rotary evaporator at $50-60^{\circ} \mathrm{C}$ until a viscous extract then phytochemical screening procedure of the extract.

\section{Characteristics test of the extract}

Visual characteristics of soursop leaf extracts observation include color, aroma, and consistency. The water content of the extract was carried out by weighing 1.0 grams of extract placed over the aluminum plate in to the Moisture Ballance instrument then operated at $105^{\circ} \mathrm{C}$ until extract dry and the percentage of water content in the extract was obtained.

\section{Detection of active compound of extract by TLC method}

Analysis of active compounds of soursop leaf chloroform extract with the Thin Layer Chromatography method. The stationary phase that used was Silica Gel $60 \mathrm{~F}_{254}$ and mobile phase: chloroform-ethyl acetate (7: 3). The spray reagents were sitoborate for the detection of quercetin and dragendorf for quinine detection. Observations were also performed under UV 254 and UV 366 light.

\section{Optimization of SMEDDS formula with SLD method}

The optimum proportion of the composition of the SMEDDS formula used three components: Tween 80-Croduret, propylene glycol, and candlenut oil with analysis by Design-Expert software. Determination of the percentage of each component werw 1: 4: 1 [upper limit] and 1: 3: 1 [lower limit]. The surfactant compositions were a combination of Tween 80 -Croduret ratio of $85 \%$ : $15 \%$. Software Design Expert would generate 14 formulas with repetition at four dots [table-1], then SMEDDS were prepared and physical stability tests included: transmittance (\%), emulsion time (seconds), and stability (F-value $=1$ ). The SMEDDS system is marked in 5.0 grams.

\section{The loading dose of Soursop leaf extract in the SMEDDS system}

The loading dose of soursop leaf extract that can be accommodated in the SMEDDS system was carried out weight series of $12.5 \mathrm{mg} ; 25.0 \mathrm{mg} ; 50.0$ $\mathrm{mg}$; and $100.0 \mathrm{mg}$ each system. Soursop leaf extract in the SMEDDS system then homogenized with a magnetic stirrer for 15 minutes, with a sonicator, and incubation into a water bath at $40^{\circ} \mathrm{C}$ for 15 minutes. Observation of solubility of the extract was done visually, then centrifugation was done at 
$6000 \mathrm{rpm}$ for 10 minutes. Observations were made on the occurrence of precipitation or separation.

\section{Optimization SMEDDS of soursop leaf chloroform extract}

Software Design Expert released 14 formulas of SNEDDS with variations of surfactant, co-surfactant, and candlenut oil components. Mixed according to the percentage of each proportion [Table-1]. The mixture was homogenized with vortex for 60 seconds, then sonication for 5 minutes and incubation into conditioned at $45^{\circ} \mathrm{C}$ for 15 minutes.

The mixture without stable extract was subsequently taken $100.0 \mu \mathrm{L}$, placed into a flask, and added with aquadest until $5.0 \mathrm{~mL}$. The mixture then vortex for 30 seconds. The mixture results were homogeneous and provide a clear visual appearance to be the first sign of successful SMEDDS formula.

\section{Observation of physical stability of SMEDDS}

The 14 formulas have been obtained by clarity test with transmittance value parameter (\%), taken $100.0 \mu \mathrm{L}$ of SMEDDS then added aquadest until $5.0 \mathrm{~mL}$ into a flask. Mixture homogenized with vortex for 60 seconds, then measured using UV-VIS spectrophotometry at a wavelength of $650 \mathrm{~nm}$, using aquadest as a blanko (Patel et al., 2011).

The emulsification time was observed by taking $1.0 \mathrm{~mL}$ of SMEDDS of each formula into $250.0 \mathrm{~mL}$ of an artificial gastric fluid solution without pepsin. AGF media made 1.0 liter that contains 2.0 grams of $\mathrm{NaCl}$ and $7.0 \mathrm{~mL}$ of $37 \% \mathrm{HCl}$ with a pH value of 1.2. Artificial gastric fluid media without pepsin was conditioned at $37^{\circ} \mathrm{C}$ above magnetic stirrer at $100 \mathrm{rpm}$. Observations were made for the time required by SMEDDS to form $\mathrm{o} / \mathrm{w}$ emulsion, then characterized by the complete mixing of SMEDDS into the media.

The stability observation of the SMEDDS system was done by the freeze-thawing method which refers to the research (Kassem et al., 2016; Senapati et al., 2016). The SMEDDS system was taken each $1.5 \mathrm{~mL}$ into the effendrof, then stored at $4^{\circ} \mathrm{C}$ and $30^{\circ} \mathrm{C}$ for $24 \mathrm{~h}$ at each temperature for six cycles, then centrifuged at $6000 \mathrm{rpm}$ for $10 \mathrm{~min}$. SMEDDS was said to be stable if there was no precipitation after centrifugation.

The observation data of physical stability were then incorporated into the Design-Expert software by providing in-range criteria [surfactant, co-surfactant, and candlenut oil]; maximum for percent transmitters; minimum for emulsion time. The optimum formula was obtained with desirability value approaching one, then compared with the SLD prediction formula with statistical analysis.

\section{Measurement of particle size and zeta potential of the optimum formula}

The taken $100 \mu \mathrm{L}$ of SMEDDS optimum formula was diluted with $5.0 \mathrm{~mL}$ of aquadest into a flask, then flipped through carefully. After that 3.0 $\mathrm{mL}$ was taken and put into cuvette to be analyzed using the HORIBA SZ-100 instrument. The particle size data obtained as the output on the computer was average particle size, particle size distribution, zeta potential, and deviation of the mean.

\section{Analysis of results:}

The proportion of optimum composition of SMEEDS formula was obtained by Simplex Lattice Design [Mixture Design] method using Design Expert 9 Trial software. The result of observation data snd prediction data of SLD was done by statistical analysis: One-Sample T-Test using SPSS software.

\section{RESULTS AND DISCUSSION \\ Characteristic of soursop leaf chloroform extract}

Determination of plants conducted in the Biology Laboratory, Faculty of Mathematics and Natural Sciences, UNS, Indonesia, showed that the plants used in this study were soursop plants [113/UN27.9.6.4/Lab/2017]. The method of extraction to pull out the active compound of soursop leaf was percolation, the advantages of this method there was a new solvent shift so that the possibility of the substance would be more sought.

In this study, chloroform solvent was chosen because according to the research of Astirin et al., (2013) that the soursop leaf fraction in chloroform solvent resulted in a higher percentage of apoptosis compared with ethyl acetate solvent in MTT test of Hela cancer cell. The randemen of soursop leaf chloroform extract was $10.25 \%$. Visual performance of soursop extract was dark green, thick in consistency, and peculiar smell extract. The water content of soursop extract was $1.3 \%$ in accordance with the requirement that the water content of the extract should be less than $10 \%$ to avoid microbial contamination (Dep.Kes, 2011).

\section{Analysis of the active compound of soursop leaf chloroform extract}

Screening phytochemical of soursop leaf chloroform extract using Thin Layer Chromatography method was done to find out 
a

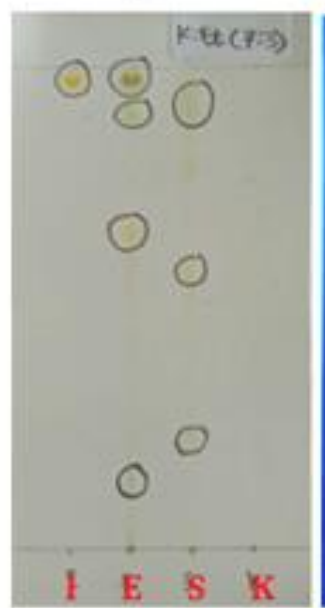

b

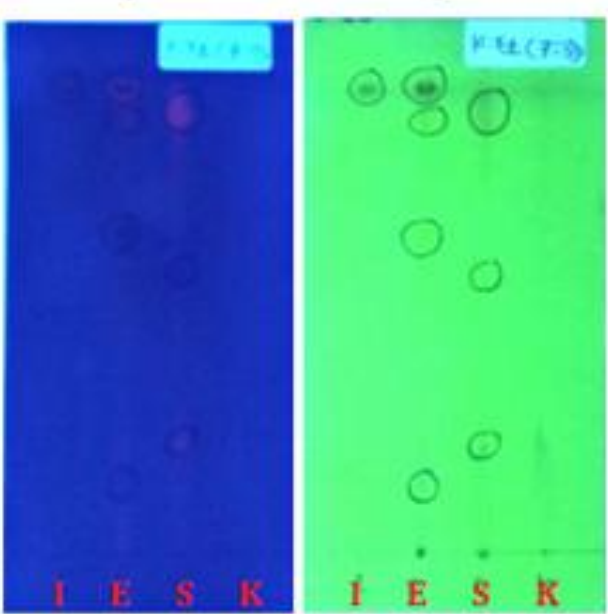

Figure 1. TLC analysis with mobile phase werw chloroform : ethyl acetate (7: 3) with Silica Gel 60 GF 254 stationary phase. Observations on visible light [a], UV 254 light [b], and UV 366 light [c]. Isolate of soursop leaf extract [I], soursop leaf chloroform extract [E], optimum formula of SMEDDS soursop leaf chloroform extract [S], SMEDDS without extract [K]

the active compound group consisted of alkaloid group test with quinine standard and spray reagent: dragendorf. Flavonoid with quercetin standard and sitroborate spray reagent. The samples positively included in the quinine alkaloid group if after being sprayed with dragendorf reagent then seen under the visible light there was an orange spot. The samples were said to be positive for the compound of the flavonoid [quercetin] group if after being sprayed with sitoborate reagent and seen under UV $366 \mathrm{~nm}$ light there was a yellow spot.

The aim of phytochemistry screening used active isolates of soursop leaf was to find out what the extract has the same content of active compound as soursop leaf isolate. According to the research of Dewangga (2015), the active isolate test of fraction soursop leaf using the mobile phase: chloroform-ethyl acetate (7: 3) produces a purplish red spot observed under $366 \mathrm{~nm}$ UV light. Figure-1 shows that the active compounds contained in the soursop leaf chloroform extract as the same as in the isolates of soursop leaf, and the SMEDDS compound was identical with the compounds in the extract. Figure 2 shows that soursop leaf chloroform extract did not contain active compounds of quinine and quercetin.

\section{Optimization of SMEDDS Formula with SLD method}

The upper limit of 1: 4: 1 and the lower limit of 1: 3: 1 which includes the oil-surfactantsurfactant coefficient, after being incorporated into the Design-Expert software was Mixture Design:
Simplex Lattice Design obtained 14 formulas which then performed physical stability analysis (Table1). The surfactant combination of Tween 80Croduret ( $85 \%: 15 \%$ ) produced particles of less than $20 \mathrm{~nm}$ (Saryanti., 2016). The loading dose of soursop leaf chloroform extracts each gram of SMEDDS system was $25 \mathrm{mg} / \mathrm{g}$, at that dose the SMEDDS system showed the optimum stability that was transmittance percent and emulsion time as required.

Candlenut oil was used as an oil phase that was long-chain triglyceride and medium-chain triglyceride which is known to have the ability to increase the bioavailability of highly lipophilic drugs by stimulating lymphatic transport (Akula et al., 2014 ). Propylene glycol was cosurfactant that safe if used orally, cosurfactants can reduce the flexibility of surface tension and may provide an interface layer that has sufficient flexibility to form microemulsions with large compositions (Senapati et al., 2016).

Physical stability parameters include transmittance percentage, said best transmittance percentage if that value closed with water transmittance value $(100 \%)$ it was mean that particle size resulting in micronizing (Ahmad et al., 2014). The next parameter was emulsification time, the self-emulsification efficiency can be estimated by determining the emulsification speed. SMEDDS should be completed fast soluble when poured into the water with low agitation within 25 seconds, it was indicated the speed of the formulation to be $\mathrm{o} / \mathrm{w}$ emulsion in AGF media (Patel, et al., 2011). Mc. Clements (2012) suggested 

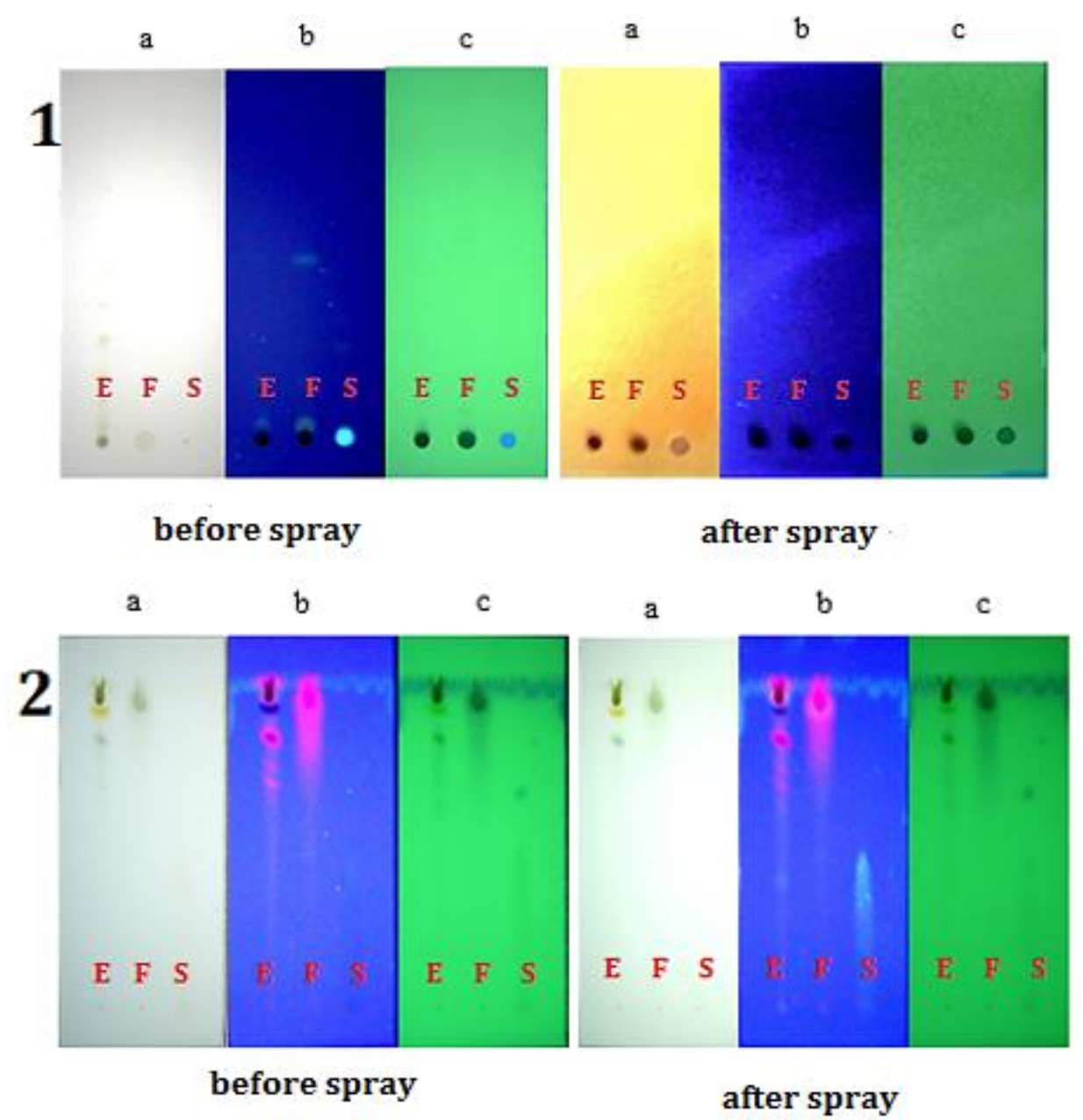

Figure 2. The results of phytochemical screening by TLC method using Silica gel phase 60 GF 254 and the mobile phase : chloroform-ethyl acetate (7: 3). Observations on visible light [a], UV 254 light [b], and UV 366 light [c]. No.1 showed detection of quinine with the dragendorf spray reagent and No. 2 showed detection of quercetin with cytoboric spray reagents. Where : soursop leaf chloroform extract [E], fraction of soursop leaf extract $[\mathrm{F}]$, and standard active compound [S]

that the o/w microemulsion was a colloidal dispersion that consists of a thermodynamically stable spherical particle (oil, surfactant, and cosurfactant) of two non-mixed liquids in which one liquid was dispersed as tiny droplets into a liquid Others. The non-settling or stable formula has a phase separation value $(F)=1$.

\section{Optimum Formula of SMEDDS of soursop leaf chloroform extract}

The experimental design was often used in research design, because it provides maximum information, but required only a few amounts of experiments. Simplex Lattice Design was one method used to optimize the proportion of formula components. The amount of candlenut oil (A), surfactant combination: Tween 80-Croduret (B), and co-surfactant: propylene glycol (C) were selected as independent factors. The characteristic of mixed profiles was determined by the Simplex Lattice Design based on the Bolton equation : $\mathrm{Y}=$ $\alpha 1(\mathrm{~A})+\alpha 2(\mathrm{~B})+\alpha 3(\mathrm{C})+\alpha 12(\mathrm{~A})(\mathrm{B})+\alpha 13(\mathrm{~A})(\mathrm{C})$ $+A 23(B) C)+\alpha 123(A)(B)(C)$. Where $Y$ was the response, $A B C$ was the proportion of the component, and $\alpha$ was the coefficient.

Statistical analysis by ANOVA explained that the response of transmittance percentage was quadratic model, responses of emulsification time, and SMEDDS stability were linear model. The model showed the effect of using candlenut oil, surfactant, and co-surfactant compositions of each formula should have a significant difference. Lack of fit explained the closeness of the observations to the predictions of the DX software. The value of lack of fit should be no significant difference between the results of research observation and 
Table I. Analysis result of 14 Formulas in 5grams system of SMEDDS with SLD method using DX software and parameters of physical stability responses of SMEDDS soursop leaf chloroform extract

\begin{tabular}{|c|c|c|c|c|c|c|c|}
\hline \multirow{2}{*}{ Run } & \multicolumn{4}{|c|}{$\begin{array}{l}\text { Percentage of Oil, surfactant, co-surfactant } \\
\text { based on SLD }\end{array}$} & \multicolumn{3}{|c|}{$\begin{array}{c}\text { Physical stability of SMEDDS soursop leaf } \\
\text { choloroform extract }\end{array}$} \\
\hline & $\begin{array}{l}\text { Oil } \\
(\%)\end{array}$ & $\begin{array}{c}\text { Surfactant } \\
(\%)\end{array}$ & $\begin{array}{c}\text { Co-surfactant } \\
(\%)\end{array}$ & $\begin{array}{l}\text { Extract (milli- } \\
\text { grams) }\end{array}$ & $\begin{array}{c}\text { Transmittance } \\
(\%)\end{array}$ & $\begin{array}{l}\text { Emulsification } \\
\text { time (seconds) }\end{array}$ & $\begin{array}{c}\text { Stability } \\
(\mathrm{F}=1)\end{array}$ \\
\hline 1 & 15.0 & 60.0 & 25.0 & 25.0 & 50.76 & 133 & 0.98 \\
\hline 2 & 16.7 & 61.6 & 21.7 & 25.0 & 59.85 & 126 & 1.00 \\
\hline 3 & 16.7 & 66.6 & 16.7 & 25.0 & 56.62 & 150 & 1.00 \\
\hline 4 & 15.0 & 65.0 & 20.0 & 25.0 & 64.93 & 189 & 1.00 \\
\hline 5 & 20.0 & 65.0 & 15.0 & 25.0 & 62.30 & 218 & 0.97 \\
\hline 6 & 15.0 & 70.0 & 15.0 & 25.0 & 60.38 & 166 & 0.97 \\
\hline 7 & 25.0 & 60.0 & 15.0 & 25.0 & 60.76 & 109 & 1.00 \\
\hline 8 & 25.0 & 60.0 & 15.0 & 25.0 & 58.46 & 112 & 0.98 \\
\hline 9 & 20.0 & 60.0 & 20.0 & 25.0 & 56.09 & 116 & 0.97 \\
\hline 10 & 21.7 & 61.6 & 16.7 & 25.0 & 58.56 & 116 & 0.96 \\
\hline 11 & 20.0 & 65.0 & 15.0 & 25.0 & 59.66 & 151 & 1.00 \\
\hline 12 & 18.3 & 63.3 & 18.3 & 25.0 & 64.52 & 146 & 0.97 \\
\hline 13 & 15.0 & 65.0 & 20.0 & 25.0 & 55.53 & 138 & 0.98 \\
\hline 14 & 15.0 & 60.0 & 25.0 & 25.0 & 51.31 & 76 & 1.00 \\
\hline
\end{tabular}

Table II. Analysis of Software Design Expert about physical stability parameters of SMEDDS of soursop leaf chloroform extract based on mathematical model and statistical analysis [ANOVA]

\begin{tabular}{lccc}
\hline $\begin{array}{c}\text { Response of physical } \\
\text { stability of SMEDDS }\end{array}$ & Mathematic Equation & $\begin{array}{c}\text { Matematic } \\
\text { s Model }\end{array}$ & $\begin{array}{c}\text { p-value [ANOVA] } \\
\mathbf{p}>\mathbf{0 . 0 5}\end{array}$ \\
\hline Transmittance (\%) & $\begin{array}{c}\mathrm{Y}=0.22871 \mathrm{~A}-2.05970 \mathrm{~B}-19.94202 \mathrm{C}+ \\
0.070715 \mathrm{AB}+0.043800 \mathrm{AC}+0.39334 \mathrm{BC}\end{array}$ & Quadratic & 0.030 \\
$\begin{array}{l}\text { Emulsification time } \\
\text { (second) }\end{array}$ & $\mathrm{Y}=1.91585 \mathrm{~A}+3.54415 \mathrm{~B}-2.79258 \mathrm{C}$ & Linier & 0.084 \\
$\begin{array}{l}\text { Sepharation phase } \\
\text { (F=1) }\end{array}$ & $\mathrm{Y}=9.52989 \mathrm{E}-003 \mathrm{~A}+9.72989 \mathrm{E}-003 \mathrm{~B}+$ & Linier & 0.739 \\
\hline
\end{tabular}

SLD prediction (Bolton, 2002). Table-2 showed that there was no significant effect on the candlenut oil, surfactant, and co-surfactant mixture on the emulsification time response and stability parameters of SMEDDS. The transmittance response parameter showed that the surfactant and co-surfactant components in the mixture had the greatest effect of increasing the transmittance percentage with the coefficient value of +0.393 .

The value in the triangle showed the composition of candlenut oil, surfactants, and cosurfactants in the model. The highest response was shown in the red area, the lower response was shown in the yellow area and lowest in the green and blue areas (Figure-3). The selected solution was the highest desirability value closed to one, which was 0.666 in the superimpose diagram which means the proportion of composition formula would produce the formula with the most optimal characteristics according to the desired target. The proportion of optimum composition of candlenut oil, surfactant, and co-surfactant was $15 \%: 60.87 \%$ : $24.13 \%$ respectively.

The prediction value obtained from the Simplex Lattice Design method showed that the predictive value of the software compare with observed response value given by the statistical analysis with $p$-value $>0.05$ and the $95 \%$ prediction interval. Based on the test results as presented in Table III, the response of transmittance percentage (clarity), emulsification time, and phase separation (stability) of the optimum formula were not significantly different from the predicted value that given by Design Expert software [p-value> 0.05].

\section{PSA and Zeta Potential Measurement of SMEDDS Optimum Formula}

Results of microemulsion droplet size in SMEDDS soursop leaf chloroform extract of 440.4 $\mathrm{nm}$ with a polidispersity index of 0.536 . Small PI 

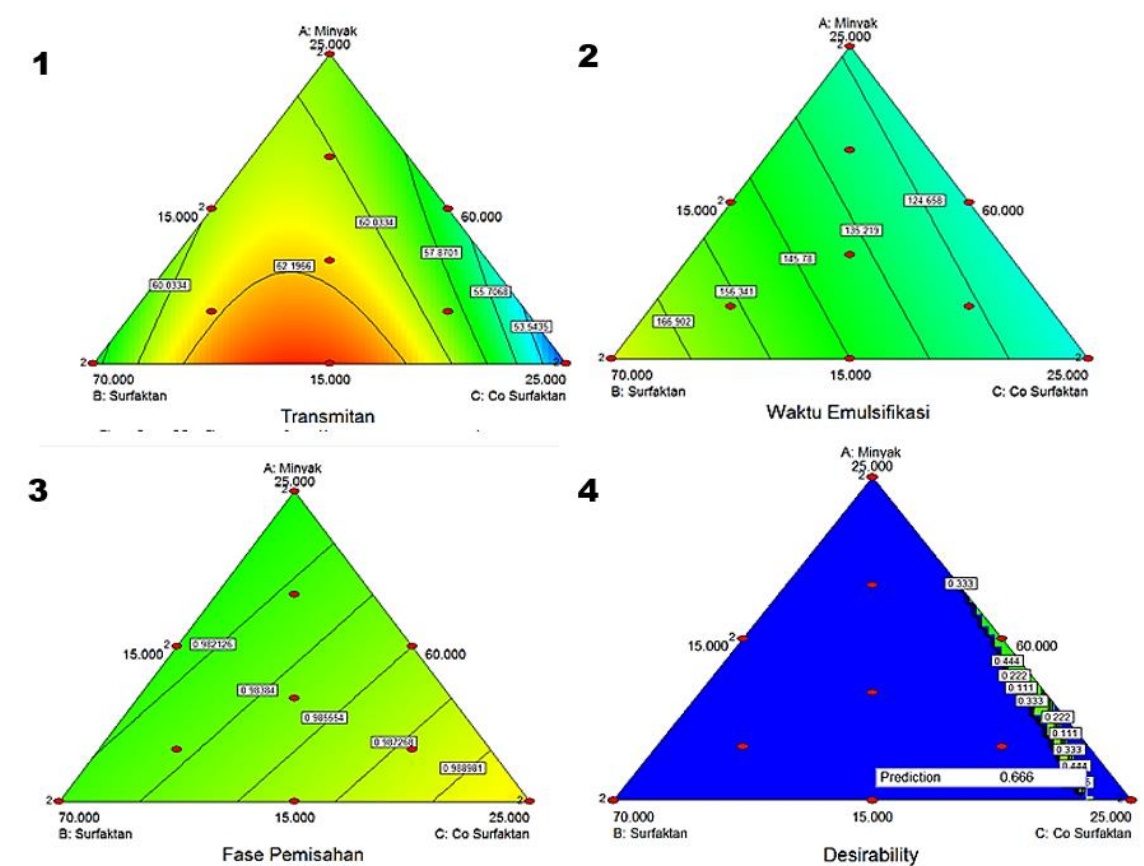

Figure 3. The counter plot diagram of the SMEDDS stability response parameter: transmitant [1], emulsification time [2], and phase of separation [3]. The super impose diagram showed that the optimum area of the candlenut oil : surfactant : co-surfactant [4]

Table III. Results of verification of SLD prediction values compare with Observation of Optimum Formula SMEDDS soursop leaf chloroform extract

\begin{tabular}{cccc}
\hline Response of physical Stability & Prediction SLD & Observation & Sig-value [p>0.05] \\
\hline Transmittance (\%) & 55.00 & $41.14 \pm$ SE 3.781 & 0.067 \\
Emulsification time (second) & 119.59 & $119.0 \pm$ SE 2.082 & 0.803 \\
Sepharation phase (F =1) & 0.99 & $0.99 \pm$ SE 0.004 & 0.226 \\
\hline
\end{tabular}

value was expected that SMEDDS could increase the bioavailability of the extract. Small particle size could increase the particle surface area to increase drug absorption. Micro size droplets would decrease emulsification time and increased absorption through lymphatic pathways so could improve the therapeutic efficacy of the drug (Bandyopadhyay et al., 2012).

Polydispersity index showed a low value of particle size distribution, it was mean that the particle size in SMEDDS was uniform (Avachat and Patel, 2014). Uniform particle size may increase bioavailability because the drug would be absorbed more rapidly at relatively similar speeds (Balakumar et al., 2013). The potential zeta value obtained from SMEDDS soursop leaf chloroform extract was $+21.5 \mathrm{mV}$. SMEDDS with the potential zeta value $\pm 30 \mathrm{mV}$ would result in a relatively stable. This positive potential zeta value indicates that the SMEDDS system has a positive and sufficient charge to counter the repulsive force so that it would produce a stable formula (Dash et al., 2015).

\section{CONCLUSION}

The proportion of optimum composition of tween 80-croduret, propylene glycol, and candlenut oil of SMEDDS soursop leaf chloroform extract was 60.87\%: 24.13\%: 15.0\% respectively. Results of transmittance and emulsification time were $41.14 \pm 3.78 \%$ and $119.0 \pm$ SE2.08 seconds respectively. The predicted SLD value for the transmittance percentage was $55.0 \%$ and the emulsification time was 119.59 seconds. The result of the statistical analysis of one sample t-test showed no significant difference between observation results and SLD prediction. The SMEDDS system has an F value of 0.99 and it was capable of loading $25.0 \mathrm{mg}$ of soursop leaf chloroform extract each SMEDDS system with an average particle size of $440.4 \mathrm{~nm}$, zeta potential $+21.5 \mathrm{mV}$ and a polydispersity index of 0.536 . 


\section{REFERENCES}

Ahmad, J., Mir, S.R., Kohli, K., dan Amin, S., 2014. Effect of oil and cosurfactant on the formation of Solutol HS 15 based colloidal drug carrier by Box-Behnken statistical design. Colloids and Surfaces A: Physicochemical and Engineering Aspects, 453: 68-77.

Ako, H., Kong, N., dan Brown, A., 2005. Fatty acid profiles of kukui nut oils over time and from different sources. Industrial Crops and Products, 22: 169-174.

Akula, S., Aravind K.G., dan Srinivas R.D. 2014. SelfMicroemulsifying Drug Delivery Systems: An Attractive Strategy for Enhanced Therapeutic Profile. Hindawi Publishing Corporation International Scholarly Research Notices, Vol. 2014.

Astirin, O.P., Anif N.A., Meutia S.F., Eva A.P., dan Adi P. 2013. Annona muricata Linn Leaf Induce Apoptosis in Cancer Cause Virus. Journal of Cancer Therapy, Vol. 4, 1244-1250.

Astirin, O.P., Adi P., Anif N.A., Meutia S.F., Witianingsih D.A., Pranatami D.A., dan Putra S.T. 2014. The Expression of P53 and hsp 70 proteins after treatment with Annona muricata Linn leaf for activating apoptotic and lead to homeostatis program of Raji cells. Int. J. Cancer Ther Oncol, Vol. 2(2), 02028.

Avachat, A.M. dan Patel, V.G., 2014. Self nanoemulsifying drug delivery system of stabilized ellagic acid-phospholipid complex with improved dissolution and permeability. Saudi Pharmaceutical Journal,

Balakumar, K., Raghavan, C.V., selvan, N.T., prasad, R.H., dan Abdu, S., 2013. Self nanoemulsifying drug delivery system (SNEDDS) of Rosuvastatin calcium: Design, formulation, bioavailability and pharmacokinetic evaluation. Colloids and Surfaces B: Biointerfaces, 112: 337-343.

Bandyopadhyay, S., Katare, O.P., dan Singh, B., 2012. Optimized self nanoemulsifying systems of ezetimibe with enhanced bioavailability potential using long chain and medium chain triglycerides. Colloids and Surfaces B: Biointerfaces, 100: 50-61.

Bolton, S. dan Bon, C., 1997. Pharmaceutical Statistics: Practical and Clinical Applications. Dekker Media.

Dash, R.N., Mohammed, H., Humaira, T., dan Ramesh, D., 2015. Design, optimization and evaluation of glipizide solid selfnanoemulsifying drug delivery for enhanced solubility and dissolution. Saudi Pharmaceutical Journal, 23: 528540.

De Melo, J.G., Thiago Antônio de S.A., Valérium T.N. de AeC, Daniela L. de V.C., Maria do D.R., Silene C. do N., Elba L.C. de A. dan Ulysses P. de A.. 2010. Antiproliferative activity, antioxidant capacity and tannin content in plants of semi-arid Northeastern Brazil. Molecules (15), 8534-8542.

Departemen Kesehatan, R., 2009. Materia Medika Indonesia, I. Departemen Kesehatan, Republik Indonesia : Jakarta.

Dewangga, VS. 2015. Karakterisasi Isolat Aktif Daun Sirsak (Annona muricata L.) dan Uji Sitotoksisitas Isolat Aktifnya terhadap Sel Hela. Universitas Sebelas Maret, Tesis.

Kassem, A.A., Mohsen, A.M., Ahmed, R.S., dan Essam, T.M., 2016. Selfnanoemulsifying drug delivery system (SNEDDS) with enhanced solubilization of nystatin for treatment of oral candidiasis: Design, optimization, in vitro and in vivo evaluation. Journal of Molecular Liquids, 218: 219-232.

Khan, B.A., Akhtar, N., Khan, H.M.S., Waseem, K., Mahmood, T., Rasul, A., dkk., 2011. Basics of pharmaceutical emulsions: A review. African Journal of Pharmacy and Pharmacology, 5: 2715-2725

Kuentz, M., 2011. Oral self-emulsifying drug delivery systems, from biopharmaceutical to technical formulation aspects. Journal of Drug Delivery Science and Technology, 21: 17-26.

Liaw, C.C., Chang F.R., Lin C.Y., Chou C.J., Chiu H.F., Wu M.J., dan Wu Y.C. 2002. New cytotoxic monotetrahydrofuran Annonaceous acetogenins from Annona muricata, J. Nat. Prod. Vol. 65 (4), 470-475.

Lynch, N. dan Berry, D., 2007. Differences in perceived risks and benefits of herbal, overthe-counter conventional, and prescribed conventional, medicines, and the implications of this for the safe and effective use of herbal products. Complementary Therapies in Medicine, 15: 84-91.

McClements, David Julian. 2012. Nanoemulsions versus microemulsions: terminology, differences, and similarities. The Royal Society of Chemistry, Vol. 8, 1719-1729.

Mc Laughlin. 2008. Paw-paw and Cancer Annonaceous Acetogenin from Discovery to Comercial Products. Department of Medicinal Chemistry and Molecular Pharmacology, School of Pharmacy and Pharmaceutical Sciences, Purdue University, Vol. 71 (7),1311-1321. 
Patel, D.M., Patel, N.M., Pandya, N.N., dan Jogani, P.D., 2007. Gastroretentive drug delivery system of carbamazepine: Formulation optimization using simplex lattice design: A technical note. AAPS PharmSciTech, 8: E82E86.

Patel, J., Kevin, G., Patel, A., Raval, M., dan Sheth, N., 2011. Design and development of a selfnanoemulsifying drug delivery system for telmisartan for oral drug delivery. International journal of pharmaceutical investigation, 1: 112.

Paulinus, O.N., Agu K., dan Eze G.I. 2013. Protective Effect of Ethanolic Leaf Extract of Annona muricata Linn on some Early Events in Cycas-Induced Colorectal Carcinogenesis in Rats. Journal of Pharmaceutical and Scientific Innovation:

Rao, S.V.R., Agarwal, P., dan Shao, J., 2008a. Selfnanoemulsifying drug delivery systems (SNEDDS) for oral delivery of protein drugs. International Journal of Pharmaceutics, 362: 10-15.

Rao, S.V.R., Yajurvedi, K., dan Shao, J., 2008b. Selfnanoemulsifying drug delivery system (SNEDDS) for oral delivery of protein drugs: III. In vivo oral absorption study.
International Journal of Pharmaceutics, 362: 16-19.

Saryanti, D., Martodihardjo, S., Martien, R., 2016. Optimasi SNEDDS Ekstrak Purwoceng Gunung (Artemisia lactiflora wall ex. DC) dan Uji Absorbi secara In Vitro. Tesis. Fakultas Farmasi : Universitas Gadjah Mada. Yogyakarta.

Senapati, P.C., Sahoo, S.K., dan Sahu, A.N., 2016. Mixed surfactant based (SNEDDS) selfnanoemulsifying drug delivery system presenting efavirenz for enhancement of oral bioavailability. Biomedicine \& Pharmacotherapy, 80: 42-51.

Wang, L., Dong, J., Chen, J., Eastoe, J., dan Li, X., 2009. Design and optimization of a new selfnanoemulsifying drug delivery system. Journal of Colloid and Interface Science, 330: 443-448.

Wang, S., Su, R., Nie, S., Sun, M., Zhang, J., Wu, D., dkk., 2014. Application of nanotechnology in improving bioavailability and bioactivity of dietderived phytochemicals. The Journal of Nutritional Biochemistry, 25:363-376.

Zuhud, E.A. 2011. Bukti Kedahsyatan Sirsak Menumpas Kanker. Agromedia Pustaka, Jakarta. 